\title{
Non-Hodgkin Lymphoma’s Therapy by CAR-T Cells
}

\section{Micaela Morais ${ }^{1 \#}$, Fernando Mendes ${ }^{2,3,4,5 * \#}$ and Rui Cruz}

${ }^{1}$ Department of Pharmacy, Polytechnic Institute of Coimbra, ESTESC-Coimbra Health School, Coimbra, Portugal ${ }^{2}$ Department of Biomedical Laboratory Sciences, Polytechnic Institute of Coimbra, ESTESC-Coimbra Health School, Coimbra, Portugal ${ }^{3}$ Faculty of Medicine, Biophysics Unit-IBILI, University of Coimbra, Portugal

${ }^{4}$ Faculty of Medicine, Center of Investigation in Environment, Genetics and Oncobiology (CIMAGO), University of Coimbra, Portugal

${ }^{5}$ CNC.IBILI, University of Coimbra, Portugal

${ }^{\#}$ Both authors contributed equally

\begin{abstract}
Lymphoma is a type of cancer that causes the proliferation of B or T cells in lymph nodes. Lymphomas can be characterized in Hodgkin Lymphoma and Non-Hodgkin Lymphoma (NHL), which account for about $85 \%$ of lymphoma diagnoses. The IS has the innate ability to identify and eliminate cells with tumor potential. Despite this, our body sometimes can't combat this type of pathologies alone due to the mechanisms of tumor escape. T cells, which are very important cells in antitumor activity, have been studied and some trials show that the use of CAR-T cells may present an added value for the treatment of this type of pathologies. The CAR-T cells are genetically modified T lymphocytes to express the specific antibody binding site, directing autologus polyclonal $T$ cells to bind to a specific Tumor Associated Antigen. The design and structure of CAR-T are determinant factors in the success of therapy. Four generations of Chimaeric Antigen Receptors (CARs) are known and the difference between they is in their signaling and costimulatory domains, such as CD28 or CD137 (4-1BB). Recent studies show effectiveness in certain cases of patients diagnosed with $\mathrm{NHL}$ and it is recognized that the combination of complementary immunotherapy enhances the effect of CAR-T cell therapy. There is still a need to clarify which the most appropriate design and which the ideal dose to maximize efficacy and reduce the toxicity of this therapy.
\end{abstract}

Keywords: Adaptive T cell therapy; CAR-T cell therapy; Immune system; Non-Hodgkin's lymphoma

\section{Introduction}

The estimated number of new cancer cases diagnosed worldwide in 2012, was around 14.1 and about 8.2 million people died of this pathology. Cancer can be associated with individual characteristics, idiosyncratic variability, environmental exposure and lifestyle. Factors such as age, alcohol, tobacco, obesity and pollution can influence the onset of cancer [1]. The lymphoma is a group of malignant neoplasms that lead to a proliferation of B or T cells in lymph nodes. We can characterize lymphomas into two groups, Hodgkin's Lymphoma (HL) and Non-Hodgkin's Lymphoma (NHL). NHL accounts for approximately $85 \%$ of all lymphomas and arises from subpopulations of white blood cells, mostly B cells. This pathology may affect the central nervous system, bone marrow, lymph nodes and a region close to the tonsilsm $[2,3]$. The immune system (IS) and its cells, such as Natural Killer cells, T cells, and other, play a key role in tumors control and suppression through diverse processes.

After recognition of tumor cells, the IS initiates defence mechanisms that aim to protect the organism. This process contemplates tree phases: elimination of neoplastic cells, the balance of the tumor (editing) and escape of the tumor. Despite oh the IS capacity for identification and elimination, some neoplastic cells are able to survive IS elimination mechanisms. Neoplastic cells have the ability to acquire selective clones or reach the steady-state phase, events that hamper the ability of the IS to control the proliferation of these cells. On the other hand, the IS may also harm the organism because the existence of chronic and persistent inflammation leading to cancer proliferation. This happens on account of factors such as genotoxic stress production, promotion of angiogenesis and tissue invasion, mechanisms that benefit the tumor microenvironment [4].

$\mathrm{T}$ cells are a very important subset of IS cells for an immune response and due to this, they are being used and studied currently as immunotherapy strategies. Adoptive T-cell therapy is an area of the immunotherapy that relies on the transfusion of $\mathrm{T}$ cells $[1,4]$. These cells can infiltrate the tumor and, when engineered, they can also acquire the ability to express specific receptors. These receptors may have the capacity to recognise the tumor antigens $(\mathrm{Ag})$ and, in the case of chimeric Ag receptors (CARs), mediates the regression of the tumor [1]. The CARs are modified receptors that target surfaced molecules, conferring T cells specificity for native cell surface $\mathrm{Ag}(\mathrm{Ag})$. CAR $T$ cells are more potent than monoclonal antibodies (also used in immunotherapy) and have the advantage of being able to provide prolonged immunity against the target Ag after a single infusion [5]. The aim of this systematic review is to understand the main mechanisms used by CARs T cell in NHL treatment and their outcome.

\section{Materials and Methods}

The literature used in this review was available in databases as "PubMed" and Coimbra Health School's Library resources. The keywords selected were "Adaptive T Cell Therapy", "Non-Hodgkin's Lymphoma," "CAR-T Cell Therapy," and the "Immune System", according to Medical Subject Headings Mesh. The inclusion and exclusion criteria were defined in order to guarantee the relevance and validity of the information. Therefore, the inclusion criteria were scientific articles, clinical trials (humans) or systematic reviews (humans), with a publication date equal to or less than 5 years,

*Corresponding author: Fernando José Figueiredo Agostinho D'Abreu Mendes Department of Biomedical Laboratory Sciences, ESTeSC Coimbra Health School, Rua 5 de Outubro SM Bispo, Apartado 7006, 3046854 Coimbra Portugal, Tel: (+351)239802430; Fax: (+351)239812245; E-mail: fjmendes@estescoimbra.pt

Received August 03, 2017; Accepted August 14, 2017; Published August 24 2017

Citation: Morais M, Mendes F, Cruz R (2017) Non-Hodgkin Lymphoma's Therapy by CAR-T Cells. J Blood Lymph 7: 175. doi: 10.4172/2165-7831.1000175

Copyright: $\odot 2017$ Morais M, et al. This is an open-access article distributed under the terms of the Creative Commons Attribution License, which permits unrestricted use, distribution, and reproduction in any medium, provided the original author and source are credited. 
availability of free full-text. The exclusion criteria were scientific articles not written in English [6].

\section{Results}

\section{NHL, T cells and immunotherapy}

NHL (as well as HL) occurs in rich immune lymphoid tissues and is therefore easily accessible by antibodies, the fact that makes it an excellent target for cellular immunotherapy. In addition, lymphomas express tumor Ag (e.g., CD19) and single tumor Ag that can be targeted by antibodies and/or effector cells [7].
As we can conclude from Table 1, T cells are very important cells throughout the process of immunovigilance and anti-tumor response. Thus, there is a need to target and manipulate $\mathrm{T}$ cells in order to increase endogenous antitumor immunity. The success of genetically engineered $\mathrm{T}$ cells therapy is dependent on engraftment and persistence of the modified cells. The genetic modification of $\mathrm{T}$ cells to confer tumor Ag recognition is typically made by transgenic expression of a high affinity $\mathrm{T}$ cell receptor or CAR. Conventional chemotherapeutic agents exhibit high toxicity which can be reduced through the use of engineered immune cells because of the precision and specificity with which therapeutic targets are recognized. Activation of $\mathrm{T}$ cells is accomplished through multiple signaling cascades induced by

\begin{tabular}{|c|c|c|c|c|}
\hline Title & Authors & $\begin{array}{l}\text { Publication } \\
\text { Year }\end{array}$ & $\begin{array}{l}\text { Type of } \\
\text { study }\end{array}$ & Subject \\
\hline $\begin{array}{l}\text { Car-T cell therapy for } \\
\text { lymphoma }\end{array}$ & $\begin{array}{l}\text { Calcagno C, } \\
\text { Lobatto ME, } \\
\text { Robson PM, } \\
\text { Millon A. }\end{array}$ & 2016 & Review & $\begin{array}{l}\text { Non-Hodgkin and Hodgkin's lymphoma are good targets for immunotherapy. Because of their } \\
\text { capacity of circumvent some of the major mechanisms by which tumors avoid MHC-restricted } \\
\text { T cell recognition, CAR's are a great promise in study for lymphoma's treatment. Despite their } \\
\text { advantages CAR's have showed some toxicity's effects. }\end{array}$ \\
\hline $\begin{array}{l}\text { Advances in cancer } \\
\text { immunology and } \\
\text { cancer immunotherapy }\end{array}$ & $\begin{array}{l}\text { Voena C, Chiarle } \\
\text { R. }\end{array}$ & 2016 & Review & $\begin{array}{l}\text { Advances in immunology lead to new therapeutic approaches of cancer's treatment. Is } \\
\text { important know the biology of the tumor and his interaction with the immune system in order } \\
\text { to develop and maximize new strategies against cancer. T cell based treatments are currently } \\
\text { under investigation for different types of tumors. }\end{array}$ \\
\hline $\begin{array}{l}\text { CD19-targeted CAR T } \\
\text { cells: A new tool in the } \\
\text { Fight against B cell } \\
\text { malignancies }\end{array}$ & $\begin{array}{l}\text { Miller BC, Maus } \\
\text { M V. }\end{array}$ & 2015 & Review & $\begin{array}{l}\text { CAR T cells are reprogramed to attack cells expressing the target extracellular Ag. } \\
\text { CAR's have } 4 \text { domains which are the extracellular } \mathrm{Ag} \text { binding domain, a hinge region, a } \\
\text { transmembrane domain, and an intracellular signaling domain. The different generations of } \\
\text { CAR design contain different intracellular signaling domains. Each successive generation } \\
\text { adding additional costimulatory domains. Despite the advantages, CAR T cells present } \\
\text { potential for significant toxicity. }\end{array}$ \\
\hline $\begin{array}{l}\text { Toxicity and } \\
\text { management in CAR } \\
\text { T-cell therapy }\end{array}$ & $\begin{array}{l}\text { Bonifant } \mathrm{CL} \text {, } \\
\text { Jackson } \mathrm{HJ} \text {, } \\
\text { Brentjens RJ, } \\
\text { Curran KJ }\end{array}$ & 2016 & Review & $\begin{array}{l}\text { A better understanding of the response of the immune system after infusion of T-cell CAR will } \\
\text { allow an improvement in treatment and scientific knowledge, which will allow the reduction } \\
\text { of the inherent risks. In the future, the toxicity resulting from this therapy is expected to be } \\
\text { anticipated and controlled, in order to improve the therapy's quality. }\end{array}$ \\
\hline $\begin{array}{l}\text { CAR T-Cell therapy: } \\
\text { The role of physical } \\
\text { barriers and } \\
\text { immunosuppression in } \\
\text { lymphoma } \\
\text { Gunilla }\end{array}$ & $\begin{array}{l}\text { Enblad G, } \\
\text { Karlsson H, } \\
\text { Loskog ASI }\end{array}$ & 2015 & Review & $\begin{array}{l}\text { CAR's consists of an Ag recognizing extracellular domain and an intracellular signaling } \\
\text { domain. Their design have influence in the therapy's response. Despite this exist others } \\
\text { physical barriers of CAR T cell infiltration. Solve CAR T cell accessibility and survival in } \\
\text { lymphoma is very important to improve these therapies. }\end{array}$ \\
\hline $\begin{array}{l}\text { Novel } \\
\text { immunotherapies in } \\
\text { lymphoid malignancies }\end{array}$ & $\begin{array}{l}\text { Calcagno C, } \\
\text { Lobatto ME, } \\
\text { Robson PM, } \\
\text { Millon A }\end{array}$ & 2015 & Review & $\begin{array}{l}\text { CAR T cells therapy reach promising results. Because of this fact immunotherapies may } \\
\text { become one of the central components of treatment strategies in lymphoid malignancies. Is } \\
\text { important to know the microenvironment associate with these tumours and understand the } \\
\text { difference in efficacy of this therapy in the different pathologies. Is also need to know the } \\
\text { mechanism of action of each treatment modality to manage and sequence each treatment } \\
\text { option for the patient. }\end{array}$ \\
\hline $\begin{array}{l}\text { CD19-targeted T } \\
\text { cells for hematologic } \\
\text { malignancies: Clinical } \\
\text { experience to date }\end{array}$ & $\begin{array}{l}\text { Davila L M, } \\
\text { Sauter C, } \\
\text { Brentjens R. }\end{array}$ & 2015 & Review & $\begin{array}{l}\text { CAR is composed of antigen-binding domains fused to cell activation and costimulatory } \\
\text { domains. CD19targeted CAR T cell are successful against B-ALL malignancies, establishing } \\
\text { themselves as a potential for cancer's treatment. The observation of an early efficacy signal } \\
\text { guarantee development of this modality into future immunotherapeutic cancer's therapies. }\end{array}$ \\
\hline $\begin{array}{l}\text { Chimeric antigen } \\
\text { receptors for the } \\
\text { adoptive T cell therapy } \\
\text { of hematologic } \\
\text { malignancies }\end{array}$ & $\begin{array}{l}\text { Davila ML, } \\
\text { Bouhassira } \\
\text { DCG, Park JH, } \\
\text { Curran KJ, Smith } \\
\text { EL, Pegram HJ, } \\
\text { et al. }\end{array}$ & 2014 & Review & $\begin{array}{l}\text { CD19 is expressed in malignant B-cell disease being expressed as a limited form in B cells, } \\
\text { but not in bone marrow stem cells. For this reason, CD19 was chosen as a target for B } \\
\text { cell malignancies. The genetic modification of autologous T cells with CARs represents a } \\
\text { breakthrough for cancer's therapy for hematologic malignancies. }\end{array}$ \\
\hline $\begin{array}{l}\text { CAR T-cells merge into } \\
\text { the fast lane of cancer } \\
\text { care }\end{array}$ & $\begin{array}{l}\text { Frey N V., Porter } \\
\text { DL. }\end{array}$ & 2016 & Review & $\begin{array}{l}\text { CARs redirect T cells to target specific tumor Ag. CAR-modified T cells with CD19 cells } \\
\text { showed remarkable activity against malignant neoplasms, including B-cell acute lymphocytic } \\
\text { leukemia (ALL), chronic lymphocytic leukemia (CLL), and non-Hodgkin's lymphoma (NHL). } \\
\text { Different generations of CARs have different outcomes, what inspire the exploration of new } \\
\text { generations. }\end{array}$ \\
\hline $\begin{array}{l}\text { Chimaeric antigen } \\
\text { receptor T-cell therapy } \\
\text { for tumour } \\
\text { immunotherapy }\end{array}$ & $\begin{array}{l}\text { Sha H, Wang } \\
\text { D, Yan D, Hu Y, } \\
\text { Yang S, Liu S, } \\
\text { et al. }\end{array}$ & 2017 & Review & $\begin{array}{l}\text { Therapies using CAR-modified T cells against CD19 is a highly effective immune treatment } \\
\text { for B-cell malignancies. There have been many trials of CAR T cells directed other tumour } \\
\text { specific or associated Ag in various hematologic malignancies and solid tumours. Despite the } \\
\text { promise of success is necessary to found a way to limit or contain CAR T cell therapy's side } \\
\text { effects. }\end{array}$ \\
\hline $\begin{array}{l}\text { Recent advances } \\
\text { in engineered T cell } \\
\text { therapies targeting B } \\
\text { cell malignancies }\end{array}$ & Singh N. & 2016 & Review & $\begin{array}{l}\text { Several clinical trials have demonstrated the success of } \mathrm{T} \text { cell therapy for B cell malignancies. } \\
\text { Efficient engineering, appropriate target selection and synthetic receptors with potent } \mathrm{T} \text { cell } \\
\text { activating domains has led to the development of highly-active cellular therapy. }\end{array}$ \\
\hline
\end{tabular}


Ag presenting cells. For complete T-cell activation, Ag recognition signals must be detected by TcR stimulation in combination with costimulation across a range of proteins such as CD28, CD27 and 4-1BB. Despite this, serious adverse effects were observed after infusion of CAR-T cells in host individuals. These adverse effects (consequent to CAR-T cell therapy) can be immediate, delayed, mild, severe and/or persistent over the lifetime of the genetically modified $\mathrm{T}$ cells. Toxicity caused by this therapy includes cytokine release syndrome (CRS), neurological toxicity, on-target/off-tumor recognition, insertional oncogenesis, and anaphylaxis, graft versus host disease and off-target Ag recognition. This toxicity can be managed through pharmacological immunosuppression, suicide genes, elimination genes and targeted activation [8-11].

\section{Car T cells}

CAR $\mathrm{T}$ cells are autologous $\mathrm{T}$ lymphocytes that are genetically modified to express the specific antibody $(\mathrm{Ab})$ binding site, directing autologous polyclonal $\mathrm{T}$ cells to bind to a specific tumor associated antigen (TAA). CAR-T cells can be used to target a highly and consistently expressed lineage- specific Ag (e.g., CD19, CD20, CD22). This results in elimination of malignant $B$ cells $[7,12]$. CARs are hybrid molecules composed of antigen-binding domains fused to the T-cell activating and costimulatory domains. The antigen-binding domain of an $\mathrm{Ab}$ re-created as a single-stranded variable fragment ( $\mathrm{scFv}$ ) and is expressed on the cell's surface. The synthetic nature of CARs allows these to be capable of targeting a variety of cancers by replacing multiple antigen-binding domains [13,14]. The CARs present 4 domains, which are an extracellular Ag binding (ectodomain), a hinge region, a transmembrane domain and an intracellular signaling domain (endodomain). The antigen-binding domain recognizes the extracellular $\mathrm{Ag}$ in their native form and does not require presentation in an MHC molecule. This will allow the CAR to function independently of the haplotype of the patient and still allow it to be used against many different extracellular ligands [7,9]. Many aspects of CAR design, such as epitope selection, affinity, hinge region length, and comparison of different combinations of intracellular signaling domains, is still under active investigation. The first generation of CAR contained a single intracellular signaling domain (CD3f) that transmitted signals to the $\mathrm{T}$ cell. This generation has a limited activity and this is probably due to the inability of first generation CARs to properly activate T cells, especially in cases where tumor cells did not express $\mathrm{T}$ cell costimulatory molecules. The activation and proliferation of $\mathrm{T}$ cells were at a low level which eventually resulted in low antitumor efficacy. Subsequently, the second generation of CARs containing one or more costimulatory domains (CD28 ou CD137 (4-1BB)) was designed, leading to improvements in $\mathrm{T}$ cell proliferation and persistence. Preclinical studies suggest that 4-1BB CARs can produce improved expansion and persistence in vivo and $4-1 \mathrm{BB}$. Third generation CARs incorporate two costimulatory domains, the former being either a CD28 or a $4-1 \mathrm{BB}$ domain and the latter provided by other molecules, such as OX40, CD28 or 4-1BB3639. Fourth generation CARs, also known as "TRUCK" $T$ cells, are designed to also express co-stimulatory cytokines or ligands, which aim to increase the expansion and longevity of T40 CAR cells $[9,12,15,16]$. Second-generation CAR-T cells are more efficient than first-generation CAR-T cells. Apparently, to ensure the success of CAR-T cell therapy, pretreatment lymphoplasty clearance prior to the infusion of CAR-T cells is required. Tumor-reducing chemotherapy and chemotherapy with lymphomaplastia are excellent allies for CAR-T cell therapy, and when administered prior to the infusion of CAR-T cells can improve the safety and efficacy profile of this treatment by reducing a number of cells inflammatory reactions in the tumor microenvironment and forming a niche for the expansion and persistence of CAR-T cells [11]. Experimental studies point to a synergistic effect between CD28 and $4-1 \mathrm{BB}$, whereas $\mathrm{T}$ cells stimulated by $\mathrm{CD} 28$ and $4-1 \mathrm{BB}$ have higher antitumor activity and greater persistence in vivo compared to $\mathrm{T}$ cells stimulated by any of these separately [10].

\section{Advantages and disadvantages of CARs Use}

CAR-T cells have the ability to bypass some of the major mechanisms by which tumors prevent recognition of MHC-restricted $\mathrm{T}$ cells, such as down regulation of human leukocyte antigen (HLA) class I molecules and defective Ag processing. CAR-t cells are also able to target non-protein $\mathrm{Ag}$, allowing them to recognize lymphoblastic tumor Ag derived from carbohydrates or glycolipids. This ability is shown to be an advantage since the conventional $\mathrm{T}$ cells receptors (TCRs) can't detect these Ag. In spite of this, the TCRs can bind any $\mathrm{Ag}$ that is presented by the MHC (major histocompatibility complex), including intracellular proteins, while CARs are only able to bind cellsurface molecules $[7,17]$.

\section{Cars's expression}

CAR-T cells must be transplanted into a subset of T cells that have the ability to target tumors. In vivo studies on the application of $\alpha \beta$ TCR + in lymphoma, therapy aim to identify, through the phenotypic profile, the ideal subset within this population. $\mathrm{T}$ cells that exhibit a memory-associated phenotype promise to be important for the in vivo persistence thereof. Some studies performed in which cells expressing a memory-associated marker (CD62L) to express CARs directed by CD19 were selected. Recently a subset of $\mathrm{T}$ cells that have a greater proliferative potential and greater survival in vivo has been identified. As an alternative to $\mathrm{T}$ cell selection based on the surface phenotype there is still the physiological selection of T cells, which have the ability to act as effector T cells, enter the memory group and re-expand on $\mathrm{Ag}$ re-exposure in vivo. There is another type of $\mathrm{T}$ cell, virus-specific $\mathrm{T}$ cells (VSTs) which in addition to this aforementioned characteristic further express chemokine receptors that allow movement to lymphoma sites. The ability of these cells to interact through their native TCR with viral $\mathrm{Ag}$ on Ag presenting cells enables the occurrence of various signals with stimulators that increase their persistence after adoptive transfer, increasing their antitumor activity [7]. The fact that most CARs based on a single-chain variable fragment $(\mathrm{ScFv})$ only recognize intact target $\mathrm{Ag}$ and expressed directly on surface cells, and also recognize peptide fragments of processed proteins that limit and hinder the ability of CAR-T cells to detect. The majority of tumor-specific antigenic epitopes [7]. CAR-t cells can be used to target a specific and consistently expressed $\mathrm{Ag}$ (such as CD19, CD20 and CD22), which leads to the elimination of malignant $B$ cells which have the common side effect of $B$ cell ablation. This side effect is relatively benign since intravenous Ig replacement therapy is feasible and circumvents the situation. However, it may be preferable to target $\mathrm{Ag}$ associated with restricted strains, such as the $\mathrm{B}$ cell maturation Ag (BCMA) [7]. In T-cell lymphomas, segmentation of an entire lineage is not as feasible or acceptable, because unlike $\mathrm{B}$-cells, the T-cell function is less accessible to replacement therapies. However, a more selective marker for a $\mathrm{T}$ cell line, such as CD30, may be an acceptable option, particularly if its expression on tumor cells is high [7]. Segmentation of single Ag implies an inherent risk of immune leakage, which can be reduced by multiple Ag. Thus, expressing various CARs on $\mathrm{T}$ cells will potentially increase safety by generating $\mathrm{T}$ cells that recognize a unique Ag pattern that is only expressed in tumor cells or in their associated stroma [7]. 


\section{CAR's effectiveness}

Many tumors, including most lymphomas, have the ability to secrete immunosuppressive cytokines, attract immunosuppressive cells, and express molecules on the cell surface that suppress immune cells, inhibit maturation of dendritic cells, and still have the ability to create an immunosuppressive metabolic environment. Although CD28 or 4-1BB endodontically mediated $\mathrm{T}$ cell costimulation in CAR molecules may mitigate some of the inhibitory effects resulting from tumor cells, other causes of energy are more difficult to combat. To overcome tumor immunosuppression, countermeasures were adopted that aim to circumvent the effects of tumor cells on the IS. These approaches include increasing the level of CAR-T cell activation or decreasing physiological down-regulation by point-of-control molecules, altering CAR-T cells by engineering so that they become resistant to inhibitory cytokines released by the tumor, and still the targeting of the cellular components of the tumor stroma [7]. An important fact to consider is that regulatory $\mathrm{T}$ cells and myeloid-derived suppressor cells are immunosuppressive cells that impair the function of CAR-T cells. Thus, there is a need to reduce its concentration by administering chemotherapy with aggressive agents so that CAR-T cells can perform their function and ensure the effectiveness of this therapy in different types of lymphomas [11]. T cells are serial killers that have the ability to expand and survive, under appropriate conditions, killing tumor cells. These can survive in vivo as effector memory cells. While an Ab only has the potential to bind only to a tumor cell and thereby induce antibody-mediated cytotoxicity, T-CAR cells proliferate in vivo and have the ability to go from tumor to tumor performing the sustained cytotoxic activity [11].

\section{CAR T cell's barriers in lymphomas}

A lymphoma is a type of solid tumor, which can cause the CAR-T cells to have some difficulty in making contact with tumor cells. A solid tumor may have a higher level of immunosuppression, with regulatory immune cells and inhibitory as proteins being concentrated in the vicinity of the tumor. CAR-T cells may also be devoid of localization receptors that allow them to penetrate solid tumors, which hinder the entire process of tumor attack. The fact that effector T cells are subject to circulation leads to them not returning to lymphatic tissues, which may disrupt the clearance of tumor cells present in the lymph nodes [11].

\section{Discussion and Conclusions}

CAR-T cells are a promising therapy to combat cancer, specifically NHL. These cells reveal the ability to bypass the mechanisms of tumor escape. Physical barriers prove to be a crucial factor in the success of this therapy. Studies have shown that these barriers can be overcome through the use of appropriately designed CAR-T cells. The differences between the different generations of CAR-T cells are in their signaling and costimulatory domains, which impart more or less efficiency to them [11]. The first clinical trial to demonstrate the significant efficacy of engineered $t$-cell therapy in the treatment of lymphomas contemplated nine patients with diffuse large B-cell lymphoma (DLBCL) and six patients with various indolent lymphomas. Of the 13 patients that were evaluable, 12 (92\%) achieved an objective clinical response and 8 (62\%) achieved complete responses lasting $>23$ months [17]. As we can see in Table 2, a clinical trial conducted in 2015 and developed in patients with B-cell malignancies reveals promising results for the association of chemotherapy regimen of cyclophosphamide and fludarabine with anti-CD19 CAR T cells (single infusion). Although one of these patients died without a known cause, the results of this trial are very promising, resulting in three positive clinical conditions: complete remission, partial remission or stabilization of clinical status [18]. Another clinical trial was conducted in 2013 in patients diagnosed with different types of lymphoma. As described in Table 2, these patients received a treatment of anti-CD19 CAR T cells and also showed promising results that translate into clinical profiles similar to those previously reported, although two patients did not respond positively to therapy [19]. It is now known that there is a synergistic effect on the association of other immunological therapies (such as chemotherapy, radiotherapy) with CAR-T cell therapy. This is a very interesting association given that the antitumor activity is amplified and the results obtained are quite promising [11]. To optimize this type of therapy it is then necessary to

\begin{tabular}{|c|c|c|c|c|c|c|}
\hline Title & Author & $\begin{array}{c}\text { Publication } \\
\text { year }\end{array}$ & $\begin{array}{l}\text { Type of } \\
\text { study }\end{array}$ & Samples & Methods & Results \\
\hline $\begin{array}{l}\text { Chemotherapy- } \\
\text { refractory diffuse } \\
\text { large B-cell } \\
\text { lymphoma } \\
\text { and indolent B-cell } \\
\text { malignancies can be } \\
\text { effectively } \\
\text { Treated with } \\
\text { autologous T cells } \\
\text { expressing an anti- } \\
\text { CD19 } \\
\text { Chimeric antigen } \\
\text { receptor }\end{array}$ & $\begin{array}{l}\text { James N. } \\
\text { Kochenderfer, } \\
\text { Mark E. Dudley, } \\
\text { Sadik H. } \\
\text { Kassim, Robert } \\
\text { P.T. Somerville, } \\
\text { Robert O. } \\
\text { Carpenter, et al. }\end{array}$ & 2015 & $\begin{array}{l}\text { Clinical } \\
\text { Trial }\end{array}$ & $\begin{array}{l}\text { Fifteen patients with } \\
\text { advanced B-cell } \\
\text { malignancies were } \\
\text { treated. (Nine patients } \\
\text { had diffuse large B-cell } \\
\text { lymphoma (DLBCL), } \\
\text { two had indolent } \\
\text { lymphomas, and four } \\
\text { had chronic lymphocytic } \\
\text { leukemia) }\end{array}$ & $\begin{array}{l}\text { Patients received } \\
\text { a conditioning } \\
\text { chemotherapy } \\
\text { regimen of } \\
\text { cyclophosphamide } \\
\text { and fludarabine } \\
\text { followed by a single } \\
\text { infusion of anti-CD19 } \\
\text { CAR T cells }\end{array}$ & $\begin{array}{l}\text { Eight patients achieved complete remissions (CRs) } \\
\text { Four patients achieved partial remissions } \\
\text { One patient had stable lymphoma } \\
\text { Two patients were not evaluable for response } \\
\text { One patient died } 16 \text { days after cell infusion (of an } \\
\text { unknown cause) } \\
\text { Toxic effects like fever,hypotension, delirium, and } \\
\text { other neurologic toxicities occurred in some patients } \\
\text { after infusion of anti-CD19 CAR T cells (these } \\
\text { toxicities resolved within } 3 \text { weeks after cell infusion) }\end{array}$ \\
\hline $\begin{array}{l}\text { Donor-derived } \\
\text { CD19-targeted } \\
\text { T cells cause } \\
\text { regression of } \\
\text { malignancy } \\
\text { persisting after } \\
\text { allogeneic } \\
\text { hematopoietic stem } \\
\text { cell transplantation }\end{array}$ & $\begin{array}{l}\text { James N. } \\
\text { Kochenderfer, } \\
\text { Mark E. Dudley, } \\
\text { Robert O. } \\
\text { Carpenter, } \\
\text { Sadik H. Kassim, } \\
\text { Jeremy J. Rose, } \\
\text { William G. } \\
\text { Telford, et al. }\end{array}$ & 2013 & $\begin{array}{l}\text { Clinical } \\
\text { trial }\end{array}$ & $\begin{array}{l}\text { Ten patients with } \\
\text { different types of } \\
\text { lymphoma were treated. } \\
\text { (Four patients had } \\
\text { mantle cell lymphoma } \\
\text { (MCL), four had Chronic } \\
\text { lymphocytic Leukemia } \\
\text { (CLL) and two had } \\
\text { diffuse large B-cell } \\
\text { lymphoma (DLBCL)) }\end{array}$ & $\begin{array}{l}\text { Patients received } \\
\text { a treatment of anti- } \\
\text { CD19 CAR T cells }\end{array}$ & $\begin{array}{l}\text { Six patients stable disease were staged as "stable } \\
\text { disease" after anti-CD19-CAR T-cell infusion } \\
\text { One patient obtained an ongoing } \\
\text { complete remission after anti-CD19-CAR T-cell } \\
\text { infusion } \\
\text {-One patient obtained an ongoing parcial remission } \\
\text { after anti-CD19-CAR T-cell infusion } \\
\text {-Two patients had progressive malignancy after anti- } \\
\text { CD19-CAR T-cell infusion }\end{array}$ \\
\hline
\end{tabular}

Table 2: Clinical trials insert in this review. 
understand and know the immune response after infusion of CAR-T cells. This knowledge provides information and makes it possible to expand studies on the activation or elimination of CAR-T cells, which reduces risks after infusion [10]. It is also interesting to identify the ideal dose of CAR-T cells to guarantee the success and maximum use of the therapy, a dose that is yet to be defined. This is a difficult task due to the resulting variation in cell expansion in vivo. This fact also imposes some questions of patient safety because it predisposes the inconsistency of the response and the toxicity they may or may not exert on the organism [12]. Although the CAR-T cells present some difficulty in penetrating solid tumors, such as the NHL. Therapy with these cells proves to be promising for patients with this diagnosis, although it is still necessary to advance in the design studies of CAR-T cells, the dose to be administered and the ideal combination of immunotherapies to be used. In this way, the beneficial effects of this therapy can be maximized and the side effects and toxicity inherent in it diminished.

\section{References}

1. Stewart BW, Wild CP (2014) World cancer report 2014. World Heal Organ.

2. Bezerra C, Figueirêdo M, Souza JR De, Handerson D, Soares G, et al. (2014) Clinical and economic aspects of the use of rituximab in non- Hodgkin's lymphoma. Brazilian J Pharm Sci 50: 445-55.

3. Buchpiguel CA (2011) Current status of PET/CT in the diagnosis and follow up of lymphomas. Rev Bras Hematol Hemoter 33:140-147.

4. Mendes F, Domingues C, Rodrigues-Santos P, Abrantes AM, Gonçalves AC, et al. (2016) The role of immune system exhaustion on cancer cell escape and anti-tumor immune induction after irradiation. Biochim Biophys Acta - Rev Cancer 1865:168-175

5. Nagle SJ, Garfall AL, Stadtmauer EA (2016) The Promise of Chimeric Antigen Receptor Engineered T Cells in the Treatment of Hematologic Malignancies 22: $27-33$.
6. Pedro E De (2009) Escala de PEDro-Português (Portugal) 1: 1-7.

7. Calcagno C, Lobatto ME, Robson PM, Millon A (2016) CAR-T cell therapy for lymphoma. Annual Review of Medicine 28: 1304-1314.

8. Voena C, Chiarle R (2016) Advances in cancer immunology and cancer immunotherapy. Discov Med 21: 125-133.

9. Miller BC, Maus M V (2015) CD19-Targeted CAR T Cells: A New Tool in the Fight against B Cell Malignancies. Oncol Res Treat 38: 683-690.

10. Bonifant CL, Jackson HJ, Brentjens RJ, Curran KJ (2016) Toxicity and management in CAR T-cell therapy. Mol Ther-Oncolytics.

11. Enblad G, Karlsson H, Loskog ASI (2015) CAR T-Cell Therapy: The Role of Physical Barriers and Immunosuppression in Lymphoma. Hum Gene Ther 26: 498-505.

12. Batlevi C, Matsuki E, Brentjens R, Younes A (2016) Novel immunotherapies in lymphoid malignancies 13: 25-40.

13. Davila L M, Sauter C, Brentjens R (2016) CD19-targeted T Cells for Hematologic Malignancies: Clinical Experience to Date. Cancer J 21: 470-474.

14. Davila ML, Bouhassira DCG, Park JH, Curran KJ, Smith EL, et al. (2014) Chimeric antigen receptors for the adoptive $T$ cell therapy of hematologic malignancies. Int J Hematol 99: 361-71.

15. Frey NV, Porter DL (2016) CAR T-cells merge into the fast lane of cancer care Am J Hematol 91: 146-150.

16. Sha H, Wang D, Yan D, Hu Y, Yang S, et al. (2017) Chimaeric antigen receptor T-cell therapy for tumour immunotherapy. Biosci Rep 37:BSR20160332.

17. Singh N (2016) Recent Advances in Engineered T Cell Therapies Targeting B Cell Malignancies. Discovery Medicine 22: 215-220.

18. Kochenderfer JN, Dudley ME, Kassim SH, Somerville RPT, Carpenter RO et al. (2015) Chemotherapy-refractory diffuse large B-cell lymphoma and indolent B-cell malignancies can be effectively treated with autologous $\mathrm{T}$ cells expressing an anti-CD19 chimeric antigen receptor. J Clin Oncol 33: 540-549.

19. Kochenderfer JN, Dudley ME, Carpenter RO, Kassim SH, Rose JJ, et al. Donorderived CD19-targeted T cells cause regression of malignancy persisting after allogeneic hematopoietic stem cell transplantation. Blood 122: 4129-4140. 